\title{
The Freedom of Choice: a snob or a gentleman?
}

\author{
Mahmut Terci Ph.D. \\ Hena e Plote Beder University \\ mterci@yahoo.com
}

\section{DOI:10.5901/mjss.2014.v5n19p165}

\begin{abstract}
Dickens explores the values of different social classes of Victorian England in Great Expectations. Born in a lower middle class family, Philip Pirrip's wish is to be part of a higher social class which would enable him to live with civilized people. Pip, as an orphan raised by hands in poor conditions, meets criminals like Magwitch and extremely rich aristocrats like Miss Havisham. Stella, allegedly illustrating a representative of the upper class at the beginning of story, almost becomes an unreachable star. At this stage, Pip is under great influences and he is not sure how to think and how to behave. Should he choose a way to stay at the forge and to work with Joe or choose a way to become a gentleman? Should he stay in a world he is loved, treated with sincerity and feeling comfortable in, or should he choose a competitive and brutal world in which he may feel completely strange? Since the word 'pip' has the meaning as 'seed', the novel is divided into three stages comparable to the growth of the 'seed': the first stage is its long waiting in the dark and cold soil, the second is its first blossom above the soil and the third is its reaching maturity and readiness to produce another seed for the future generation. At the beginning, Pip is obviously in the first stage. Miss Havisham's dark house and Estalla's cold behavior may be compared to the stage of the seed waiting in the dark, cold soil to grow out of it. Pip's second stage is his 'blossoming' in London, not as a gentleman, but as a snob. What will the third stage be: will he remain as a snob or will he turn into a gentleman? Whatever it will be: it will be his free choice with his free will.
\end{abstract}

Keywords: gentleman, Charles Dickens, Great Expectations, true gentleman, snob

\subsection{Introduction - The Humble Origin}

Unlike Oliver in Oliver Twist and Nicholas in Nicholas Nickleby, who have noble roots on their father's line, described as gentlemen of birth or of wealth, Pip, whose original name was Philip Pirrip, and from Great Expectations appears to be an orphan raised by his brother in law, an ordinary blacksmith from the lower class. The reasons why Dickens prefers to use the short form of Pip's name are several. First, he connects his lower class position with the name 'Pip' which also means a 'pip-card' or 'a low card in a card game, namely beggar-my-neighbor';1 second, he makes a connection to his 'potential' with the other meaning of the word which is 'a small seed' 2 .

Pip lives with his sister, who has been cruel to him, and her blacksmith husband, Joe - the only person he really liked due to his friendly, lovely, kind, respectable and sincere attitudes. While his sister makes him 'timid' and 'sensitive' as a result of her 'unjust' behavior and 'unfair' punishments, Joe has a great influence on forming his personality. Joe represents the Christian values, such as showing his sincere love and respect and forgiveness in any circumstances to the people although he is illiterate and lacks gentle manners.

In the novel, Pip, who writes about his childhood with hindsight, criticizes his sister in various ways. First, he thinks that she lacks politeness. Second, Pip believes that irrespective of the amount of good that someone has done for other people, he or she should never boast of it. So Pip dislikes bragging. Third, the fact that Pip is very sensitive and timid is considered to be the effect of his sister's unkind and unfair behavior. What Pip feels about his sister is that he is useless or a burden that should be gotten rid of as soon as possible. A kind of punishment is set - by Dickens - later caused by her unkind behavior towards other people around her as well. On the contrary, Pip admires Joe in many ways. The main reasons why Pip likes Joe more than his own sister are the facts that Joe behaves like a friend, listens to him carefully, shares his

\footnotetext{
${ }^{1}$ See Kirsten L. Parkinson "What do you play, boy?: Card Games in Great Expectations” Dickens Quarterly Vol.27, No. 2, June 2010, p.121

${ }^{2}$ See http://dictionary.reference.com/browse/pip?s=t
} 
problems, respects him and, more importantly, sees and appreciates Pip as a separate individual, as a grown-up person. Joe prefers to be humble as a result of his kind heart. As he calls himself 'common' frequently in the novel, he is respected and admired a lot. He embodies a shelter in which Pip hides and finds peace in his intimacy.

Dickens also adds professional symbols to the place, the forge, where Joe works. The 'forge', a hot place, also standing for Joe's heart is the place where, whenever the 'weather', i.e. the problems in the real life, is cold, the 'heart' will provide warmth. That is why Joe and his place have a close connection in terms of 'heat', seen both literally and figuratively. Another possible interpretation is connected to the fact that Joe is the very essential person in shaping Pip's character. At work, Joe heats the 'iron' in the forge until it is 'softened' and hammers it to give its final shape. Joe is one of the most important characters having a great influence to Pip's final identity, who gives him the final touch, in the novel. Although Joe, who represents a humble character in the lower class, is illiterate and does not have gentlemanly manners, his social values and religious commitments such as his sincere love, forgiveness and respect to people are very strong like his muscular strength due to working at the forge. Joe is described as "the source of positive, life giving energies," a view which will be analyzed in detail later, by R. Gilmour who points out some other crucial facts about him:

He is the possessor of a 'great nature' (ch.57), and in a book where feelings take a violent and sometimes self-destructive form he shows Pip a constancy and generosity of affection and instinctive tenderness, which go a long way towards mitigating his wife's severity. (Gilmour, 132)

There are some other important characters like Magwitch, Miss Havisham, Estella and Herbert who have a great importance in the plot as well. While Pip is brought up 'by hand', by his sister, his 'coarse hands' are laughed at by Estella, he is pushed into a fire by Miss. Havisham's hands and he is given a helping 'hand' by Magwitch, Herbert and Joe, respectively, during the hard process of his getting new identity.

\subsection{Two Eccentric People: Magwitch and Havisham}

In the first chapters of Great Expectations, Dickens creates a thrilling atmosphere for the readers. He makes the main character, Pip, meet 'his convict', Magwitch, in the marsh far away from his sister's home. First, he is terrified when he encounters him. Pip is wildly threatened to bring him some food and a file. Terrorized by the fugitive's threats with an imaginary young man who takes out heart and liver with his command, Pip feels compelled to help him. However, he feels guilty because he has stolen some food and a file from home.

Since the novel is published in periodicals Dickens creates suspense for each chapter. The thrilling atmosphere starts with the 'terrorized' little boy. This is his first encounter with an outlaw of criminal world. Pip feels guilty because he is helping a criminal and moreover he has stolen from his sister, like a criminal. He thinks that he has become part of the crime with this 'engagement'. When Pip accompanies Joe with the soldiers in search of the fugitives he thinks that his convict may suspect that Pip has deceived and betrayed him. In the story, it could be guessed why Pip was so afraid for deceiving his convict as he could be punished or destroyed by him later when he is caught. But actually he is afraid of having the dishonorable label of betrayer. Already having the seed of a true gentleman's nature, Pip cannot bear to live with a shame like that. When they come face to face, he tries to tell him that he is not the person who has brought the soldiers there. The facial expression keenly noted by Dickens also tells a lot of things to the people who can understand it, as does the way the characters look at each other. In Pip's situation, looking in the convict's eyes was the only way in which he could communicate when he tried to explain that he was innocent. Dickens reveals Wagwitch's 'look' as 'my boy' later, by the end of the story. Pip's 'my convict' becomes his future benefactor and Magwitch's 'my boy' becomes his respectable gentleman in London.

There are some other important points that have to be mentioned. On the one hand, Pip's help of the convict is rewarded later in his life, although young Pip had not been aware of this fact for a long time. Pip's little but gentle gesture inspires Magwitch to make this little poor boy a gentleman. Actually, the revenge of his number-one-enemy, namely Compeyson, undermines this plan, but, eventually, this behavior, Pip's unrequited help, motivates him in his choosing the right person. On the other hand, Miss Havisham's revenge, trying to make Pip fall in love with the beautiful Estella, a devilish plan caused by her hatred of all men, will make him suffer. While Magwitch's revenge makes Pip a gentleman of wealth, Miss Havisham's vengeful plan makes him a miserable lover, whose heart is broken like hers. Magwitch, like a 'magician', creates a respectable gentleman out of his 'hat' (i.e. his wealth), but Miss Havisham's grief becomes a 'heavy' burden and a great 'shame' (a play on the words 'heavy shame' and 'Havisham'), which she pays for with her life. Eventually, she becomes aware of the dreadful thing she has done, when in her last meeting with Pip she cries 'what have I done' and she deeply regrets having hurt innocent feelings. 
From another perspective, looking at the Dickens's way of inventing the names of the two 'witches', Magwitch could have resulted from the contraction between 'magnificent' and 'witch', while Havisham may come from 'heavy sham' or from helluv and sham, through the elision of 'hell of'. In either case, 'sham' means pretense, fake, fraud and counterfeit. Although their intentions differ, the two witches concurrently, manage to drag Pip into the world of snobs and gentlemen. While the magnificent witch - with a good intention - pushes him into the world of a magnificent paradise, helluv sham - with an evil intention - drags him into hell or a fake paradise. Gilmour also points out the readers' possible confusion in terms of these two eccentric people's relations with Pip. According to him,

Miss Havisham is a grotesque version of Aunt Betsey, an eccentric single lady who in taking Pip up seems to have recognized his innate fitness to become a gentleman, but as her name suggests she is a sham, a witch, while the money that makes Pip's pursuit of gentility possible come from another 'witch', Magwitch, and thus from the underworld - literally the underworld of Australia where he has made his money, and symbolically from the social underworld of crime with which he is associated in Pip's mind for most of the novel. (Gilmour, 116)

Not only these two characters' personal ambitions and their plans on Pip, but also Pip's own natural desire to be civilized and to improve his own intellectual capacity meet in the same personality, which will make him unwillingly confused in his subsequent decisions. It becomes a great decision for him to choose to live in his old humble town or in aristocratic London and then to choose either to behave like a snob or a gentleman. No matter when and where civilizations emerged, big cities have always been the centre of people's attractions for various reasons. The sense of wonder to see the wonderful outcomes of the civilization -from art to architecture, from technology to entertainment, and from people's lifestyles to their social systems -, the ambition of lower people to live in better life conditions and the desire to improve one's intellectual capacity in various fields of science, make the various kinds of people choose larger cities, which, allegedly, represent civilization better than the rural areas.

Pip's ambition to become a gentleman is fired when he meets Estella, who is brought up according to the values of the upper class. As soon as Pip is humiliated in his simple and rude way of naming the cards and in his possessing of 'coarse hands' and 'thick boots', he starts questioning his own culture and his world. The 'cultural shock' causes the seed (the 'pip'), genetically implanted in Pip, to grow and awakens his great dreams for the future. Pip's future benefactor's proposal becomes a great opportunity for him, which should not be missed in the achievement of his own great expectations. Pip realizes that he might only reach his "star" (Estella), by becoming a gentleman. Estella, who has the heart filled with 'ice', is indeed a 'starter' for Pip. She is the first person who starts that 'fire', a reference to his ambition to be a civilized and educated person, in his inner world. We might think that Pip's desire is only to become a member of the upper class, to enjoy their benefits, rather than to fulfill a sexual desire. This perspective will be investigated later in the next sub-chapter.

\subsection{The First Impacts and Great Expectations}

Leaving back - but keeping in mind - Pip's adventure with his convict, a set of stunning events start with his visit to Miss Havisham's house. One of the snobs in Great Expectations is Mr. Pumblechook, who makes plans to learn more about the strange-single-recluse, and bumbles around a chook (Miss Havisham) in the hope of benefitting somehow from wealth. That's why Uncle Pumblechook finds a kind of job for Pip at Miss Havisham's house.

Pip is shocked when he sees the old lady in her old yellowish bride dress. He also notices that her watch and the clock in the room 'had stopped at twenty minutes to nine' (GE, 57). Seeing the eccentric old lady with an awkward appearance who had never left the room since her dramatic misfortune, who wanted diversion, and who had sick fancies to have someone play around her is an abnormal thing which Pip tries to understand.

\section{'So new to him,' she muttered, 'so old to me; so strange to him, so familiar to me; so melancholy to both of us! Call}

Estella.' (GE, 58)

In these lines, Dickens uses a few metaphors and symbols in order to give various interesting messages about the upper class. We see that a little common boy from the lower class is invited to a house which belongs to a rich lady. First of all, Pip and the readers expect to see better and richer conditions as well as fantastic or normal people. Playing again with stereotypical images, Dickens shows that everything is deeply strange in this world. The whole atmosphere is strange and melancholic: from the old lady's unusual dress to her watch and the frozen clock in the room, from her sick fancies to her broken heart, from her weird behavior to the strange topic she embarks upon ("I want diversion, and I have done with men and women" 58), Dickens, who knows the world of the two social classes, criticizes the values of the upper class to portray its 'real' face to his middle and lower class readers. According to him, this world should not be exaggerated in people's 
imagination, because the reality is completely different. This world is so strange and so melancholic that it makes its people look peculiar. The way they are dressed, the way they behave, the way they talk, the way they look, the way they entertain and the way they see and interpret the things that happen is rather strange than elegant and gentlemanly. In analyzing these two worlds with Dickens, Gilmour claims that Dickens had experienced the two worlds subjectively,

in all their complexity and ambivalence. But in one marvelous novel, Great Expectations (1860-1), he found a fictional form capable of expressing the social ironies underlying both his own and his generation's preoccupation with the idea of the gentleman and, in doing so, delivered what is in many ways his most profound commentary on Victorian civilization and its values. (Gilmour, 107)

This world is 'new' and 'strange' to Pip. It is 'old' and 'familiar' to Miss Havisham. Yet, it is 'melancholic' to both. Dickens connects Miss Havisham's 'melancholic' mood to her 'grief' (a reference to her lover's betrayal), but he connects Pip's 'melancholic' perception of the whole scene to the values of the upper class, which is very difficult to be amazed at or to admire. There are no bright colors and 'light' turns off in this world. Because the 'sun' or the 'light' as a source of energy (i.e. moral values), does not enter Miss Havisham's house, everything in her place and in her society turns bleak and melancholic.

Since Miss Havisham hates every man in the world, she composes a play whose main actors will be Pip and Estella. And the main theme will be taking revenge on men by breaking a heart into pieces and, unfortunately, Pip is chosen for the role. Being unaware of what is really happening, the innocent child becomes a vulnerable victim in the hands of a vicious witch. That's the outline of the play whose scenario was written by Miss Havisham, the producer and the director. Estella, whose heart has been filled with ice, is used like a weapon against Pip. Pip, coming from a common family, is scorned and mocked at by this supercilious girl who has been brought up by Miss Havisham. His coarse hands, his thick boots, and the way he calls the cards become instruments for severe insult and humiliation.

This is the first 'cultural shock' which has a deep impact on Pip. Dickens throws his seed into the heart of a rich witch. Being called a 'common' boy and owning 'coarse hands' and 'thick boots' are the real facts about his social status. The two ladies' disdainful behavior leads him to dislike his social position and his poor possessions. It may be easily claimed that the brutal torturing, which has caused Pip to be ashamed of his social status and of his 'coarse hands' and 'thick boots' for the first time in his life, is one of the worst things that might happen to an innocent and vulnerable child. Dickens also implies that in this 'fantastic' world of the rich, there are cruel people who take sadistic pleasure humiliating the people from the lower class. Portraying such scenes, Dickens sends messages to the members of both classes. While he warns the lower or middle class people that they might encounter such cruel people in their attempts to climb the social ladder, he also reminds the upper class people that there are people as innocent and sensitive as Pip whose dreams and illusions may be easily broken. This kind of behavior never matches true gentlemanliness, which was supposed to be an indispensible characteristic of the civilized people.

Returning to the story, Pip is taken to Miss Havisham's house for a very simple reason, to play which is what his relatives and readers never expected. Dickens, who sees people as actors and actresses playing their roles on the stage, entertains his readers with surprising developments in his well-woven plot. At the beginning of the novel, things develop in a very strange way when little Pip finds himself in the world of merciless figures. The names 'Pip', 'Estella', the term 'beggar' and the card game 'beggar-my-neighbor' have been chosen professionally by Dickens. They are wonderfully connected to each other. It is strange that Pip should be the loser in multiple games. Why does Pip lose the game all the time? Why does Miss Havisham hysterically ask Estella to beggar Pip?

Kristen L. Parkinson, who made a research on card games in Great Expectations, suggests that "Estella's multiple victories are symbolic, emphasizing the psychological power she has over Pip", because according to the mathematician Marc Paulhus's calculations "the probability that one player wins a single game of beggar-my-neighbor is never greater than 60 percent unless the game is played only with court cards." (Parkinson, 121-22) It is obvious that Dickens creates a miserable atmosphere for Pip for the melancholy in the house to pass on to him. The grief caused by his losing the games, the humiliations and the whole melancholic scene infects Pip. Dickens, we might say, uses all the possible instruments to drag his character into a melancholic atmosphere.

Dickens prefers to use the short form Pip to Philip also because a 'pip card' is a low card as is any numbered card whose value is lower than faces cards, (Parkinson, 121). Dickens implies both Pip's low position socially and his poor knowledge and intellectual strength at that moment. Estella, whose name comes from Latin and means star, is placed in a high position or station which Pip has to struggle for to win or even reach her level. This could be a reference to her class 
status, her intellectual performance (higher than Pip's) and to her hard-to-reach heart. This certainly becomes one of Pip's great expectations in the first stage of the novel.

The word 'beggar' is used both as a noun and as an adjective in the passage. Pip is a 'beggar' compared to Estella and Miss Havisham, but he is also meant to be 'beggared', that is to be mentally and psychologically 'ruined,' 'destroyed. Miss Havisham's plan is to make Pip smitten by Estella's beauty and to desperately beg her to marry him. Estella, on the other hand, is a fake. She is born in the lowest layer of the low class, yet she is educated by Miss Havisham to become a lady and behave as if she were born in the upper class. Therefore, Estella's poor, criminal origin (her mother was a murderess) is revealed in the scene in which she gets pleasure in 'animal aggression'. Gilmour pinpoints this fact and uses the PipHerbert fight scene in order to show her real face:

The brief scene enacts the supreme paradox of Pip's life: Estella can only respond to him when he exhibit those qualities of physical force and animal aggression which, in order to win her, he is at pains to civilize out of himself. It [her kiss] is her one spontaneous gesture to Pip and he misreads it, feeling only guilt and remorse at this exercise of his blacksmith's arm. (Gilmour, 139)

What we add to this behavior is the fact that Estella is just a 'symbol' who represents the cold face of adopted society. Pip had never come across such humiliation before and he started to judge his question in the society and asked Joe why they have not brought him up more 'genteelly'. The only person he knows around him with whom he can share his problems is Joe, so he asks him without hesitation why they were called common. Joe listens to Pip carefully and first reminds him that lying is a wrong behavior:

'There's one thing you may be sure of, Pip,' said Joe, after some rumination, 'namely, that lies is lies. However they come, they didn't ought to come, and they come from the father of lies, and work round to the same. (GE, 69)

Then, instead of preaching about their social position, he sincerely encourages Pip that he is 'uncommon' and 'uncommon scholar'. He means that Pip is different and he trusts his capacity. Joe believes that one day Pip will take his education and he will admire Pip's scholarly progress. Joe's natural naivety and his real trust in Pip do not only sooth him, but they also give him positive energy for the future. He thus refreshes Pip's hopes for the future.

'Well, Pip,' said Joe, 'be it so or be it son't, you must be a common scholar afore you can be a oncommon one, I should hope! (GE, 69)

Joe's encouragement of Pip's education is important for Pip's future. Pip's infected mind and soul is healed in Joe's 'coarse' hands, 'gentle' heart and 'life giving' soul. After this awful experience in Miss Havisham's house, Pip sees his weak points, namely ignorance and gentle manners. He decides to take lessons from Biddy in reading and writing. Dickens's approach to class issues and the necessity of education are among the most important in the novel. The working class, the lower class, the middle class or 'common' people in general are also the part of the cultural mosaic and their ways of life should be respected, protected and promoted to the younger generations. Estella's behavior - as a result of Miss Havisham's teachings - is extremely offensive and unlady-like.

Miss Havisham's mistake is the generalization of an incident her having been left by a fake gentleman just before the wedding, which causes her hatred of all the male people. Dickens underlines two important facts about human psychology using Miss Havisham's unfortunate love affair. The first one is that people sometimes start blaming everybody for a personal bad treatment. Secondly, when people find themselves in a low or bad situation, they look around to see whether they alone or not. Seeing other fallen people as they are sooths them. To be clearer, Miss Havisham wants to see a brokenhearted gentleman who has been abandoned by his female lover that is the reverse of her situation. Pip becomes the candidate for the 'broken-hearted' gentleman. Miss Havisham's devilish plan starts to work and Pip begins to think differently. Eventually, he starts to feel ashamed of his home, of his coarseness and commonness. The ambition to become a member of the upper class occupies his feelings and thoughts completely. A desire for a change is fired in Pip's mind and heart.

Years pass and Pip becomes a teenager. One day he decides to visit Miss Havisham on her birthday. The main reason seems to be his wish to see Estella there, but he finds out that Estella had gone abroad to be well educated. Pip feels a malignant, evil pleasure in her words. Pip shows the signs of the desire for a change in his own world. He feels more dissatisfied with his home, his work and everything nearby. The readers may suppose that it is because of the love that he could not utter openly to Estella. But the desire to become a gentleman is far beyond that. In his mind, it is a kind of new, superior world that he thinks he is willing to find. People will respect him, he will be treated 'genteelly', he will have a high standard of living and, more than that, he will have distinguished intellectual perspectives that he would like to share with 
peers in this new world. This is a scene that Miss Havisham has been looking forward to seeing, since she invited a boy to play at her place. Seeing Pip in a miserable situation makes her happy. His miserable look makes her laugh and Pip thinks that she feels a cruel and heartless pleasure at his humble origin and human suffering.

Playing with someone's innocent feelings and honor, which is what Miss Havisham has been doing with Pip, is an awful behavior which honorable, open hearted people cannot easily live with. We notice that Pip never bursts out condemning her, never uses a bad language, and never breaks her heart at all. He always becomes patient and behaves positively. With this kind of positive behavior in all circumstances he reveals what makes a person a true gentleman.

Another example, which indicates Pip's gentlemanly quality, is that he tries to find excuses in himself not in the others. As soon as he gets the bad news about his sister while he was living in London, he comes home to see her. He finds out that his sister has been severely injured after a malicious attack. He first blames himself. Thus, we see that whatever the problem may be, true gentlemen look for their own mistakes at themselves and try to work out for solutions. Dickens implies that people should question themselves first in various problems before starting to blaming the others and trying to figure out who is the real culprit. In Turkish there is an idiom which means 'the fire burns the place where it falls.' 1 but, adapted to the portrait of the true gentleman, it becomes 'wherever the fire falls it burns me as much as the others.' 2 This is also Pip's case. Although he is not directly responsible what has happened to her sister, he blames himself about the incident.

While struggling with his own problems, Pip shares his own feelings and thoughts with Biddy, the girl who teaches Pip how to read and moves to their place to take over housekeeping duties as Mrs. Joe cannot move due to her illness. Meanwhile, they develop a close friendship and one day he confesses to her that he wants to become a gentleman. $\mathrm{He}$ shares his secret thoughts with her:

\section{'Biddy,' said I, after binding her to secrecy, 'I want to be a gentleman.' (GE, 125)}

Pip also explains to Biddy why he wants to be a gentleman. Biddy tells him that Estella is not worth winning over. Her words should not be cared at all. Being a common person is not a case which anybody should get ashamed of. She convinces him that there is nothing to be ashamed of and comforts him by telling him that it is not worth being a gentleman just for another person's sake. Biddy represents the wisdom of the middle class people while revealing real pedagogical and human gifts. Pip starts to believe that there is nothing wrong being a common person in the lower class, but being a gentleman does not mean only a class shift in the social status. To him, the gentleman is a person who is civilized, has fine manners and is intellectually enlightened. This perspective coincides with Dickens's approach to the image of the gentleman in his time.

From time to time, Pip's sudden thoughts come to his mind and like a dream they take him far away. In other words, his mind inevitably becomes busy with future thoughts, dreams and expectations. He still expects something good - a kind of fortune or financial aid - from Miss Havisham. Pip moves into a new stage. While he has some great expectations for his future, he struggles with himself in the attempt to form his identity. And he does not have any financial opportunity or guide to help him.

Unexpectedly, Pip's great expectation to become a gentleman is refreshed when Miss Havisham's lawyer turns up and tells him the good news! Being considered as a 'distinguished' individual and being called Mr. Pip sound like a song in Pip's ears and he cannot believe it. Although he has some hesitations, he himself is determined to achieve great expectations. To us, these expectations are mainly to obtain a respectable status in the society, a better education, to be able to practice his intellectual capacity. Pip does not decide to become a gentleman because he feels inferior or because he secretly hates his own people. It is true that Pip has been humiliated and is still in shock, but these elements have worked like a match to start up a fire. In other words, these elements have contributed to his ambition to find his own identity, to achieve his dreams, to get a good education, to experience a higher standard of life in the upper class and to get a chance to prove to himself that he is special - with Joe's words 'oncommon scholar' -. When he shares his decision with Joe and Biddy, they congratulate him, but Pip feels a touching sadness in their voices. Joe and Biddy consider Pip to be "a gentleman of fortune," meaning that he is destined to have a better future. However, Pip resents their sadness wrongly interpreting it as selfishness. On the other hand, he feels that he may not be up to their expectations that he may achieve better things in his life.

Pip has different expectations, though he is overwhelmed by gloomy thoughts, anxieties, doubts and uncertainties. Meanwhile, hot discussions take place on the matter. Lines, such as "he [Joe] is rather backward in his learning and his

\footnotetext{
${ }^{1}$ Anonyms 'Ateş düştüğü yeri yakar.'

2 Anonyms 'Ateş nereye düşerse düşsün o beni de yeri yakar.'
} 
manners!" (GE, 145), "He may be too proud to let anyone take him out of a place that he is competent to fill" (GE, 146) create some of Pip's future doubts concerning his relation with Joe. The negative consequences are also mentioned. In the end, Pip asks them to understand the opportunity, which should not be missed at all. He confesses that it has always been his dream to become a gentleman and he had always speculated what it would be like if he were a gentleman. It has always been his dream to rise to a higher position intellectually, financially, and morally in the society.

Therefore, I made no remark on Joe's first head: merely saying as to his second, that the tidings had indeed come suddenly, but that I had always wanted to be a gentleman, and had often and often speculated on what I would do, if I were one. (GE, 145)

With this important decision he steps on to a new stage. Will Pip's decision lead him to a fall or a rise? Will he become a snob or a true gentleman?

\subsection{Conclusion - The Freedom of Choice}

Pip arrives in London, meets new people and especially Herbert who helps him a lot and gives him hints about polite manners. Although Pip remembers the fight they had a long time ago in Miss Havisham's garden, Herbert becomes his best friend with whom he can share everything. There are other surprising turns of the plot. For instance, Pip finds out later that his secret benefector is Magwitch, the convict whom he has once helped. The roles of these people are to mould Pip's personality in the process of his joining gentility. There are some other surprises in the novel, such as Estella's rejection of his love, her marriage decision to his number-one-enemy, Estella's being Magwitch's only daughter, the truth about Orlick's attacks on him and his sister, Miss Havisham's changing behavior towards him. Why did Dickens put this kind of interesting and unexpected surprises in the story, then?

First, as mentioned before "the novel is published in 36 weekly parts in ALL THE YEAR ROUND (December 1, 1860 August 3,1861 )" (Davis, 126). So, it can easily be guessed that Dickens placed exciting coincidences throughout the book, especially at the end of each chapter. Second, Dickens lays a special emphasis on the fact that today's enemy could be your close friend tomorrow or today's close friend could be your fierce enemy tomorrow. Readers are surprised when they figure out that Herbert and Magwitch play important roles in his achieving great expectations. Yet, Herbert, who once had a fight with Pip, and Magwitch who, once frightened and threatened Pip during his escape, are the characters who contribute the most to Pip's growth into an ideal gentleman. Third, a true gentleman or a lady should behave kindly and positively to everybody, whether close friends or cruel enemies. This requirement in the gentlemanly code is rooted in human kindness on the one hand, and in the Christian code of behavior, on the other. If we look from this Christian-centric perspective, it is quite easy to make people be closer to each other, to help them solve their problems, and to enhance mutual love, respect and kindness.

Pip's childhood enemy, Herbert, becomes his best friend, teaches him good manners, saves his life, and helps him when he loses everything. The fugitive who threatens to kill him when he was a small child turns into his financial benefactor. Miss Havisham who enjoys Pip's sufferings feels regrets and, in the end, becomes one of his financial supporters. Thus, Pip sees the results of his positive and gentlemanly attitudes to these people in his life.

Herbert teaches him not only the manners of a gentleman, but also the facts about Miss Havisham and Estella. One of the surprising things which Pip learns from Herbert is the fact that "Estella has been brought up by Miss Havisham to wreak revenge on all the male sex." (GE, 175) Pip finds out the reason behind this awful behavior. A con-man, who proposes to marry Miss Havisham, does not only deceive her financially but he also jilts her on her wedding day. It is tragicomic that Miss Havisham generalizes her specific problem related to the specific person and then she hates the whole male sex as a result of this generalization.

Herbert also believes that Pip needs to learn the most important requirements to form a correct image of the gentleman, which will guide him in his relationships with the others. This important lesson actually comes from Herbert's father, Matthew Pocket, who believes that "a true gentleman at heart is a true gentleman in manner" (GE, 179). When they discuss about the con-man who has left Miss Havisham, Herbert's father's advice is highly noticeable and important about the idea of the gentleman, which reflects Dickens's approach to the issue.

When Pip is in London, he meets Drummle-like-'snobs' from wealthy families. The lavish feasts and the snobbish lifestyle generally influence Pip in a negative way. Not only his own snobbish behavior, but also the symptoms of discontentment with his past show how deeply he is 'infected' by this new life and by his new friends. For a while, Pip behaves like a snob after he gets used to his life in London. We think that Dickens also aimed at distinguishing true gentlemanliness from 
snobbery. He makes his main character fall into snobbery first and introduces Pip's, Joe's and Biddy's reactions afterwards, revealing what he considers to be 'ill-mannered' behavior. This type of behavior is used to show Pip's need to be woken up from his 'sleep' or 'unconsciousness'. In other words, Pip will be led to realize how awfully he has behaved and wonder why he has behaved that way. With Joe's and Biddy's help he questions himself and figures out his mistakes. The first example is when he comes home from London for the first time and he decides to stay at the Blue Boar Inn rather than go home. The new gentleman, Mr. Pip, thinks that he would feel uncomfortable staying in his old house with Joe and Biddy. The second example is when "Pip walks through town [and] the tailor's boy mocks his snobbery and elegance in the street by pretending not to know him." (Davis, 130) (Bold mine) The third example is when Joe comes to London to visit Pip and he is shocked by Pip's formality and, consequently, Joe starts to addresses his companion 'sir'. Joe naturally observes that Pip feels very uncomfortable with his visit. Joe easily feels the anxieties in Pip's behavior and interprets this as Pip's wish not to be close with him any longer, because Joe sees that they are now members of different worlds and classes. Yet, Pip feels uncomfortable because he anticipates that his 'new' friends would laugh at him when they see him with Joe, the coarse blacksmith.

There are other snobs in the novel, like Drummle, and Pip is sure that they will insult Joe as soon as they meet him. They will probably laugh at the way he is dressed, the way he talks and the way he behaves. Joe is one of the most important people in Pip's life and he does not want him to fall into an embarrassing situation. However, Pip cannot explain all these things to Joe and feels that Joe might misunderstand him.

Dickens has rightfully chosen the name 'Drummle' for his snob, as it suggests the hollow noise which a 'drum' makes. Dickens implies that Drummle has no heart and that is why he may easily insult the people around. He also chooses this character to be Estella's future husband so that he matches an empty-hearted 'gentleman' with a cold-hearted 'lady' as a kind of punishment. It looks like a punishment for Pip too, though at the end the readers realize it was not. Before leaving London, Joe manages to get to Pip's heart once more. Pip feels ashamed of the way he has talked to Joe and realizes that somehow he has hurt his dignity and pride. However, Joe forgives him later because of his love for everybody and everything when Pip gets severely ill. Joe looks after him for weeks by his bed and even pays all his debts, expecting no gratitude, just out of his good heart, thus revealing the qualities of a 'gentle Christian man'. Whenever Pip opens his eyes in his fever, he sees Joe's figure staying with him in London and taking care of all his needs. Pip realizes Joe's natural dignity and makes a connection with the qualities that he has acquired naturally in his own world and to his old and new values. According to Pip's considerations, Joe is a true Christian gentleman as he does not love and forgive Pip but he also tenderly cares for him and sincerely helps him without any expectations. That's why Pip later describes Joe as a 'gentle Christian man' to give special emphasis on the Christian values that would make a real gentleman, as opposed to the fake gentle manners of snobs he met in his new world in London. In other words, Pip clearly sees that Joe's real gentle manners acquired naturally in the lower class, backgrounding his religion, are far better than the fake gentle manners he acquired in the upper class. While he lives unpleasant moments with the people he really respects and cares, like Joe, because of his wrong attitude, he also receives a cold response from the people he over appreciates, like Estella and Miss Havisham.

Meanwhile, when Pip starts to notice that the things and the events around him have good and bad influences on him, he regrets dreaming of unreachable expectations, having met Miss Havisham, having fallen in love with Estella, living in a world in which he cannot be helpful to anyone. He questions his position in life and realizes he would be happier if he lived in front of the humble and honest fire at the forge and in the old kitchen. Pip understands that the honest and humble life with Joe and Biddy did not look so attractive in the beginning, when compared with the luxurious life in the city. Now, he wishes to get back the relieving comfort, sincere, humble and rich atmosphere of the forge and home. The luxurious life in London may look bright and shiny from the outside, but when living it, the expected comfort is lost and the great expectation turn into great nonsense. Dickens also chose the words 'forge fire' and 'kitchen fire' carefully, because it is a hard, exhausting and hot process to shape a piece of iron in the furnace at forge. And it is also a hard, exhausting and hot process to cook a meal in the kitchen. In order to make something useful from an iron a blacksmith has to put it into in the furnace so that he can soften it to shape it as he wishes. And in order to make something delicious to eat, the ingredients have to be mixed up in a pot and then put on the fire to be cooked. The hot process, also a reference to the unbearable sufferings he went through, to Joe's touching words and to Estella's decision to marry to Drummle, heats Pip like an iron in the forge or a pot on the stove, which, figuratively, shapes a true gentleman.

A number of emotional shocks hit Pip. First, his sister dies. As soon as he gets the news, he returns home for the funeral. The clouds, a reference, perhaps, to Pip's new problems, seem to go away. The sufferings make Pip's character stronger. He now feels closer to the values of his previous life with Joe and Biddy. Dickens gives his final touches and transformations 
to Pip in his third stage of life. The deep and gradual change in Pip's character is described by Hasan Cakir, the author of the book entitled Fundamentals of Fiction (2003), as follows:

It is clear that there is a deep and gradual character development in Pip by the last chapter. Pip realizes that his great expectations have come false. He is now happy to get rid of his dreams. In chapters fifty-seven and fifty-eight, his character change is underlined in his reconciliation with Joe and Biddy. He decides to love his true friends. Having forgiven his enemies, Pip has been prepared his old friends again. (Cakir, 121)

Dickens shapes a gentleman respecting and having been guided by the Christian values. Loving and being generous to his friends, forgiving enemies and being kind and gentle to everybody are considered to be important components of one's character. For the first time in his life, Pip feels an extra-ordinary pleasure when he behaves in this way. On his twenty-first birthday he receives a huge amount of money from Jaggers to pay his debts. Pip gets Wemmick's advice for a good investment and uses this money to advance Herbert's prospects. Supporting his closest friend financially, when he is in the deepest need, makes Pip very happy and he admits that this has also become a turning point in his life:

I did really cry in good earnest when I went to bed, to think that my expectations had done some good to somebody. A great event in my life, the turning point of my life, now opens on my view. (GE, 295)

Helping other people is in fact a turning point in his life. His closest friend, Herbert, becomes the first person who is given financial aid to improve his business. Miss Havisham, Estella and Magwitch will be the other figures in the novel who will be helped by Pip later. According to Dickens, true gentlemen are the people who consider the benefits of the others first and their own later. Selfishness cannot find a place in their hearts. They live to make the others live comfortably. They forget their own desires.

As mentioned before, Dickens usually chooses the names for certain purposes. We have already explained the roles of the two 'witches' (Magwitch and Havisham) in Pip's evolution. From another perspective, Dickens chooses contradictory names for these characters which have little connection with the real roles they have in the process of the shaping of Pip's personality. Pip thinks that his 'witch' might be harmful to him, but discovers later that he is his secret benefactor whose aim is to mould Pip into a gentleman form. Miss Havisham thinks that her 'admirer' would be her future husband, but he becomes the devious and wicked gentleman whose role is to 'come' and 'pay' for any offspring (i.e.'son') that would have existed (Com-pey-son). Her 'adoptive' children - Estella and Pip - have been brought up differently. While Estella's heart is filled with hatred as a result of Compeyson's psychological damage to Miss Havisham's mind and heart, Pip's heart is filled with love, which he shows from the very beginning when he offers help to the convict. So Dickens points out that his wicked gentleman has to come and pay (he does pay in the end with his life) for what he having harmed Miss Havisham, directly and Estella and Pip, indirectly. Thus, Dickens's message is clear: not only the names, but also the appearance and the devious or deceptive behavior of the people are just only 'covers' through which the 'real faces' are revealed.

Dickens is also keen on showing that people may change dramatically throughout their lives. Miss Havisham confesses that she has done wrong and she also admits that she has raised a girl who tantalized and tormented him severely. They have similar pains which resulted from having been abandoned and not having been shared their love. Miss Havisham feels worse than Pip because she had planned the entire scenario. However, she reminds him that she has human feelings in her heart and she begs his pardon. Being noble, a gentleman, Pip forgives her. In this last meeting Miss Havisham's dress catches on fire and Pip plays an important role to extinguish the fire although he is also injured in the process. Dickens gives death penalty to the wicked gentlemen, Compeyson and Orlick, who never feel guilty or regret their wickedness and do not raise any affection with the readers. However, the two witches' death, Magwitch's and Miss Havisham's, are considered are not as violent because they feel guilty about the mistakes they have done and they have shown their good intention in helping Pip when he needed it. Magwitch, Estella's father, and Miss Havisham, Estella's step-mother, play important roles in the fashioning of Pip's personality. Through their direct and indirect influences and by experiencing the two worlds, Pip tries to achieve his great expectations.

Estella remains a 'star' to Pip, a star he cannot reach at all in the original version and ending of the novel. In the second version - as the happy ending was a public requirement - they meet at Satis House again and, as they leave "the ruined place," Pip says that he sees "no shadow of another parting from her." (GE, 478) implying that they may get together and live happily ever after. In this respect, Philip V. Allingham claims that: 
The futile love affair with Estella - bright, and distant, and cold as the stars for which he has named her - reflects young Dickens' own hopeless infatuation with a banker's daughter, Maria Beadnell. Significantly, in the original ending Dickens did not reward Pip for his struggles by arranging the traditional happy ending for the lovers. 1

This particular elusive situation "I saw the shadow of no parting from her." (GE, 478) can be interpreted in various ways so that we can notice Dickens's artistic touch and modernity in his works. An ordinary reader expects a happy ending matching Pip and Estella at the end as they seem to understands their mistakes and feel sorry for them. Other readers might think that Estella does not represent a particular person, but a particular class, so Pip becomes the admirer of the upper class, of their culture and life standards. Instead of marrying into that class and staying there for ever, Pip prefers his humble origin and he connects the two worlds remaining in the lower class as a true gentleman. To other readers, Pip's low 'love' turns into a mystical true 'love' that he starts to feel for everybody else. Thus, sometimes Dickens's elusive tone in the novel creates different readings suitable for all tastes and capacity of understanding.

In conclusion, we observe Dickens has given a special emphasis in Pip's psychological development in Great Expectations. His achievement may come from the fact that Dickens himself was not used to be a gentleman. Like the narrator in the novel, he becomes a gentleman later in his life. As an outsider and then as an insider - seeing and living in both worlds - the upper- and the mid-lower class -, Dickens describes Pip's evolution from an ordinary person to a snob, from a snob to a true gentleman. Dickens, who observes and describes not only the people, places and the incidents which he comes across in his life, but also his own feelings and thoughts vividly deserves great admiration for his genius in portraying his colorful characters and building such intricate plots. With Great Expectations Dickens shows how difficult and long the process of shaping one's personality is. It is even harder to make a character a true gentle man living in harmony with different worlds.

\section{References}

Cakir, Hasan. (2003). Fundamentals of Fiction: An Analysis of Fundamental Literary Elements in Fictitious Works, Cizgi Kitabevi, Konya. (p.121)

Davis, Paul. (2007). Critical Companion to Charles Dickens, A Literary Reference to His life and Work, Facts On File, Inc. New York. (p.126)

Dickens, Charles. (2002). Great Expectations Penguin Books Ltd, 80 Strand, London WC2R ORL, England (Electronic Edition)

Gilmour, Robin. (1981). The Idea of the Gentleman in the Victorian Novel, London: Allen \& Unwin, (pp.107-140)

Parkinson, Kirsten L. (2010). "What do you play, boy?: Card Games in Great Expectations." Dickens Quarterly Vol. 27, No. 2, June (p.121)

\section{Internet Resources}

An Introduction of Charles Dickens's Great Expectations http://www.victorianweb.org/authors/dickens/ge/pva10.html Philip V. Allingham, An Introduction to Charles Dickens's Great Expectation Faculty of Education, Lakehead University, Ontario http://www.victorianweb.org/authors/dickens/ge/pva10.html

Word Entry, pip, http://dictionary.reference.com/browse/pip?s=t

Mahmut Terci Ph.D. is the Deputy Principal at the International Computer High School of Constanta. He teaches general English and gives Cambridge IELTS courses for high school students. His fields of interest and research are British and American culture, and methodology in ELT. He worked at SELT Publishing as a writer publishing ELT course books, reading and grammar books for young learners, namely, Speed Up-Course Book 2, Get to Point 3, Speed Up-Grammar 2. He has participated to national and international conferences, and presented a paper about "Online Testing" in INGED, Ankara (2005). He has currently done a PhD research on the English gentleman in Victorian Culture and in Charles Dickens's fictions at the Faculty of Letters, Ovidius University, Constanta.

\footnotetext{
${ }^{1}$ See Philip V. Allingham, An Introduction to Charles Dickens's Great Expectation Faculty of Education, Lakehead University, Ontario http://www.victorianweb.org/authors/dickens/ge/pva10.html
} 